\title{
IMPLEMENTASI SEKOLAH RAMAH ANAK DAN KELUARGA DI SDN 2 HEGARSARI, SDN KALIGINTUNG, DAN SDN 1 SANGKAWANA
}

\author{
Dyah Indraswati ${ }^{1^{*}}$, Arif Widodo ${ }^{1}$, Aisa Nikmah Rahmatih ${ }^{1}$, Mohammad Archi Maulyda ${ }^{1}$, \\ Muhammad Erfan ${ }^{1}$ \\ ${ }^{1}$ Program Studi Pendidikan Guru Sekolah Dasar, Fakultas Keguruan dan IImu Pendidikan, \\ Universitas Mataram, Mataram 634918, Indonesia \\ *) E-mail: dyahindraswati@unram.ac.id
}

\begin{abstract}
Abstrak
Kasus kekerasan terhadap anak yang terjadi di sekolah menjadi salah satu alasan program Sekolah Ramah Anak (SRA). Penelitian ini dilakukan di tiga SD di tiga provinsi yang berbeda yaitu Jawa Barat, Daerah Istimewa Yogyakarta, dan Nusa Tenggara Barat. Lokasi penelitian adalah SDN 2 Hegarsari, SDN Kaligintung, dan SDN 1 Sangkawana. Penerapan Sekolah Ramah Anak (SRA) akan dievaluasi dengan merujuk pada 6 komponen yaitu kebijakan SRA, pelaksanaan kurikulum, pendidik dan tenaga kependidikan terlatih hak-hak anak, sarana dan prasarana SRA, partisipasi anak, partisipasi warga diluar sekolah. Penelitian ini menggunakan pendekatan kualitatif. Subyek penelitian adalah kepala sekolah, guru, tenaga kependidikan, orang tua siswa, dan beberapa siswa kelas 6 . Teknik pengumpulan data menggunakan observasi, wawancara, dokumentasi, dan tinjauan literature. Validitas data dilakukan dengan triangulasi sumber. Teknik analisis data untuk penelitian kualitatif terdiri dari reduksi data, tampilan data, dan verivikasi data. Kesimpulan dari penelitian ini menunjukkan bahwa ketiga SD yang menjadi subyek penelitian sudah menjadi sekolah ramah anak baik secara fisik maupun non fisik, meskipun ada beberapa sarana yang harus dilengkapi. Ketiga sekolah secara umum sudah menjadi tempat yang aman dan nyaman bagi siswa dalam melaksanakan proses belajar.
\end{abstract}

Kata kunci: implementasi, keluarga, sekolah ramah anak

\section{Implementation of Children and Family Friendly Schools in SDN 2 Hegarsari, SDN Kaligintung, and SDN 1 Sangkawana}

\begin{abstract}
Cases of violence against children that occur in schools are one of the reasons for the ChildFriendly School (SRA) program. This research was conducted in three elementary schools in three different provinces, namely West Java, Yogyakarta Special Region, and West Nusa Tenggara. The research locations were SDN 2 Hegarsari, SDN Kaligintung, and SDN 1 Sangkawana. The implementation of a Child-Friendly School (SRA) will be evaluated by referring to 6 components, namely the SRA policy, curriculum implementation, educators and education personnel trained in child rights, SRA facilities, and infrastructure, child participation, citizen participation outside school. This research uses a qualitative approach. The research subjects were the principal, teachers, education staff, parents of students, and several 6th-grade students. Data collection techniques used observation, interviews, documentation, and literature review. Data validity is done by source triangulation. Data analysis techniques for qualitative research consist of data reduction, data display, and data verification. The conclusion of this study shows that the three elementary schools which were the subject of the study have become child-friendly schools both physically and non-physically, although several facilities must be equipped. The three schools, in general, have become a safe and comfortable place for students to carry out the learning process.
\end{abstract}

Keywords: child-friendly school, family, implementation

\section{PENDAHULUAN}

Meningkatnya kasus kekerasan terhadap anak yang terjadi di sekolah menjadi salah satu alasan perlunya program Sekolah Ramah Anak (SRA). Tidak jarang pelaku kekerasan 
Indraswati, et al., JKKP 7 (1) (2020) 51-62

terhadap anak adalah warga sekolah seperti guru atau teman sebaya. Dalam catatan World Conference (1995) di Beijing dirumuskan arti dari kekerasan adalah setiap tindakan yang dapat menyebabkan kerugian atau penderitaan fisik, seksual, atau psikologis, termasuk ancaman untuk melakukan tindakan tersebut, pemaksaan atau perampasan kemerdekaan (Pasalbessy, 2010). Kekerasan juga merupakan tindakan yang disengaja sehingga dapat mengakibatkan cidera fisik atau tekanan mental. Campbell dan Humphrey dalam Yani, S. A (2008) mendefinisikan kekerasan anak sebagai setiap tindakan yang mencelakakan kesehatan dan kesejahteraan anak yang dilakukan oleh orang yang seharusnya bertanggung jawab terhadap anak tersebut (Soeli, Djunaid, Rizky, \& Rahman, 2019).

Terry E Lawson dalam Solihin (2014) membagi kekerasan anak menjadi 4 macam antara lain emotional abuse, verbal abuse, physical abuse, dan sexual abuse. Kekerasan Emosional (emotional abuse) merupakan kekerasan yang tidak terlihat, kekerasan ini menimbulkan perasaan tertekan dan tidak nyaman. Bentuk kekerasan ini biasanya pemberian julukan yang mengandung hinaan atau membuat seseorang menjadi bahan lelucon Poerwandari (2008). Kekerasan verbal adalah kekerasan menggunakan kata-kata seperti memfitnah, mengancam, menakut-nakuti, menghina, meneror, dan menyalahkan (Putri \& Santoso, 2012). Menurut Banner dalam Patnani, Ekowarni, dan Etsem (2002) kekerasan fisik (physical abuse) adalah perlakuan dalam bentuk pemukulan yang bisa menyebabkan luka (ringan, berat, bahkan kematian). Kekerasan fisik dapat menyebabkan dampak buruk baik fisik maupun psikis. Banyak penelitian yang membuktikan kekerasan fisik dapat menyebabkan gangguan perilaku di kemudian hari. Kekerasan seksual (sexual abuse) terhadap anak adalah pemanfataan anak dalam segala bentuk aktivitas seksual yang terjadi sebelum anak tersebut mencapai batas umur tertentu untuk kesenangan seksual. Tindakan kekerasan seksual terhadap anak misalnya menyentuh organ seksual anak, memperkosa, sodomi, menunjukkan alat kelamin, dan sebagainya (Maslihah, 2006).

Komisi Perlindungan Anak Indonesia (KPAl) mencatat pada tahun 2019 masih ditemukan kekerasan yang terjadi di lingkungan sekolah. Masih ada kasus guru dan pihak sekolah yang memberikan hukuman fisik pada siswa yang "nakal" sehingga berdampak buruk bagi anak. Misalnya, kasus dua siswa di SMA TI kota Palembang yang meninggal saat kegiatan Masa Pengenalan Lingkungan Sekolah (MPLS). Seorang siswa SMP Kristen Mapanget Manado yang meninggal setelah dihukum lari keliling lapangan sekolah karena terlambat. Tidak hanya kekerasan pada siswa saja, seorang guru di SMK Ichthus di Manado juga tewas ditikam siswanya karena menegur siswanya yang ketahuan merokok (Kumparan, 2019).

Komisioner bidang pendidikan menuturkan KPAI menerima 153 kasus pengaduan kekerasan fisik dan bullying selama tahun 2019. Kekerasan fisik dan bullying tersebut $39 \%$ terjadi di jenjang SD/MI, 22\% terjadi di jenjang SMP/sederajat, dan 39\% terjadi di jenjang SMA/SMK/MA. Jumlah siswa yang menjadi korban mencapai 171 orang, sedangkan jumlah korban dari pihak guru sebanyak 5 orang. KPAI mendapati sebesar $44 \%$ kasus dilakukan oleh oknum guru dan kepala sekolah, $13 \%$ dilakukan siswa ke guru, $13 \%$ dilakukan oleh orang tua siswa, dan 30\% dilakukan antar siswa. Alasan oknum guru melakukan kekerasan dengan dalih mendidik dan mendisiplinkan siswa, oknum orang tua siswa melakukan kekerasan karena ingin membela anaknya. Adapun alasan siswa melakukan kekerasan adalah untuk membalas dendam (Kumparan, 2019).

Sekolah seharusnya menjadi lembaga yang membantu keluarga dan masyarakat menyiapkan generasi yang memiliki kemampuan fisik, kognitif, dan karakter yang baik sehingga nantinya mereka mampu menjalankan perannya di masyarakat. Sekolah harus dirancang sebagai tempat yang nyaman untuk belajar, tempat berkomunikasi untuk membangun kreativitas, dan difasilitasi dengan berbagai fasilitas yang memadai seperti laboratorium, perpustakaan, teknologi informasi, olah raga, music, dan sebagainya. Tindakan kekerasan yang terjadi di sekolah membuat pola perilaku belajar siswa yang seharusnya tumbuh dengan baik menjadi tidak baik (Kuntoro, A, Sodiq, 2010). Pertumbuhan dan perkembangan anak yang mengalami child abuse berbeda dengan anak normal pada 
umumnya. Dampak langsung yang terjadi 5\% mengalami kematian, 25\% komplikasi serius seperti cacat, patah tulang, dan luka memar. Kekerasan pada anak juga bisa menyebabkan kerusakan permanen pada susunan saraf sehingga mengakibatkan retardasi mental, masalah belajar, masalah dalam perkembangan motorik, kejang, ataksia, ataupun hidrosefalus.

Tabel 1. Bentuk kekerasan di lingkungan sekolah

\begin{tabular}{|c|c|c|c|c|c|c|c|}
\hline \multirow[b]{2}{*}{ No. } & \multirow[b]{2}{*}{ Jenis Kekerasan } & \multicolumn{3}{|c|}{ Jumlah } & \multicolumn{3}{|c|}{ Presentase (100\%) } \\
\hline & & Guru & $\begin{array}{l}\text { Teman } \\
\text { Sekelas }\end{array}$ & $\begin{array}{c}\text { Teman } \\
\text { Lain Kelas }\end{array}$ & Guru & $\begin{array}{l}\text { Teman } \\
\text { Sekelas }\end{array}$ & $\begin{array}{c}\text { Teman } \\
\text { Lain Kelas }\end{array}$ \\
\hline 1. & Menjewer & 326 & 226 & 134 & 31,8 & 22 & 13,1 \\
\hline 2. & Mencubit & 379 & 504 & 316 & 36,9 & 49,1 & 30,8 \\
\hline 3. & Menendang & 70 & 261 & 175 & 6,8 & 25,4 & 17,1 \\
\hline 4. & $\begin{array}{l}\text { Memukul dengan } \\
\text { tangan }\end{array}$ & 118 & 297 & 191 & 11,5 & 28,9 & 18,6 \\
\hline 5. & $\begin{array}{l}\text { Memukul dengan } \\
\text { benda }\end{array}$ & 107 & 208 & 112 & 10,4 & 20,3 & 10,9 \\
\hline 6. & $\begin{array}{l}\text { Menghukum hingga } \\
\text { jatuh sakit, pingsan }\end{array}$ & 29 & 23 & 19 & 2,8 & 2,2 & 1,9 \\
\hline 7. & $\begin{array}{l}\text { Melukai dengan } \\
\text { benda berbahaya }\end{array}$ & 11 & 36 & 23 & 1,1 & 3,5 & 2,2 \\
\hline 8. & Kekerasan fisik lain & 32 & 49 & 32 & 3,1 & 4,8 & 3,1 \\
\hline 9. & $\begin{array}{l}\text { Membandingan } \\
\text { dengan saudara / } \\
\text { anak lain }\end{array}$ & 176 & 172 & 130 & 17,2 & 16,8 & 12,7 \\
\hline 10. & $\begin{array}{l}\text { Membentak dengan } \\
\text { suara keras dan kasar }\end{array}$ & 357 & 357 & 254 & 34,8 & 34,8 & 24,8 \\
\hline 11. & $\begin{array}{l}\text { Menghina dihadapan } \\
\text { teman / orang lain }\end{array}$ & 133 & 298 & 212 & 13 & 29,0 & 20,7 \\
\hline 12. & $\begin{array}{l}\text { Menyebut "bodoh" } \\
\text { "pemalas", "nakal", } \\
\text { dsb }\end{array}$ & 226 & 264 & 183 & 22 & 25,7 & 17,8 \\
\hline 13. & $\begin{array}{l}\text { Mencap dengan } \\
\text { sebutan jelek/ jahat }\end{array}$ & 56 & 151 & 108 & 5,5 & 14,7 & 10,5 \\
\hline 14. & $\begin{array}{l}\text { Kekerasan psikis } \\
\text { lainnya }\end{array}$ & 19 & 25 & 13 & 1,9 & 2,4 & 1,3 \\
\hline
\end{tabular}

Sumber: KPAl, 2013

Menurut Widiastuti \& Sekartini (2005), perkembangan kejiwaan anak yang mengalami kekerasan juga mengalami gangguan antara lain: (1) Kecerdasan, berbagai penelitian melaporkan terdapat keterlambatan dalam perkembangan kognitif, bahasa, membaca, dan motoric; (2) Emosi, masalah yang sering ditemui antara lain gangguan emosi, kesulitan belajar, kesulitan berinteraksi dengan teman, kehilangan kepercayaan diri, agresif, cenderung menarik diri, temperamen, susah tidur, dan berperilaku tidak wajar; (3) Konsep diri, anak yang mengalami kekerasan sering merasa dirinya jelek, tidak dianggap, tidak dicintai, tidak bahagia, tidak dikehendaki, muram, bahkan bisa melakukan percobaan bunuh diri; (4) Meniru perilaku kekerasan yang terjadi pada dirinya pada orang lain; dan (5) Sexual abuse bisa menyebabkan nyeri/penyakit pada organ vitalnya bahkan anak bisa mengalami kelainan seksual atau bertingkah laku yang kurang sesuai dengan umurnya.

Pasal 28B ayat (2) UUD 1945 menyatakan "setiap anak berhak atas kelangsungan hidup, tumbuh, dan berkembang serta berhak atas perlindungan dari kekerasan dan diskriminasi". Merujuk pada hasil riset KPAI, sekolah belum bisa menjadi tempat yang ramah bagi anak. Meskipun disebut sebagai institusi pendidikan, tapi tidak jarang kekerasan tumbuh dan 
berkembang di sana. Sekolah seharusnya menjadi tempat yang menyenangkan bagi anak, karena anak-anak akan dididik untuk saling mengenal dan menyayangi (Qosim, Nugroho, Islam, Islam, \& Magelang, 2015). Banyaknya kasus terhadap pelanggaran anak, membuat kita sadar perlu adanya program untuk mewujudkan kondisi yang aman dan nyaman, yang mampu melindungi anak dari kekerasan dan diskriminasi selama anak berada di lingkungan sekolah. Konsep sekolah ramah anak perlu digalangkan sebagai upaya mengondisikan sebuah sekolah memenuhi hak anak dan melindunginya. Sekolah ramah anak merupakan salah satu indicator dalam pengembangan Kabupaten/Kota layak anak. Pembentukan dan pengembangan SRA didasarkan pada prinsip-prinsip nondiskriminasi, kepentingan terbaik bagi anak, perkembangan dan kelangsungan hidup, penghormatan terhadap pandangan anak, dan pengelolaan yang baik (PPPA, 2015).

Berdasarkan fenomena ini, maka dilakukan penelitian tentang implementasi Sekolah Ramah Anak terutama di jenjang Sekolah Dasar. Penelitian ini berupaya mengungkap apakah di SD sudah benar-benar menerapkan Sekolah Ramah Anak atau belum. Penelitian ini dilakukan di tiga SD di tiga provinsi yang berbeda yaitu Jawa Barat, Daerah Istimewa Yogyakarta, dan Nusa Tenggara Barat. Pemilihan lokasi didasarkan karena kemitraan peneliti dengan guru dan alumni di sekolah tersebut sehingga lebih banyak informasi yang diperoleh. Lokasi penelitian pertama adalah SDN 2 Hegarsari yang berlokasi di Jl. Raya BanjarPangandaran No. 284, Hegarsari, Pataruman, Kota Banjar, Jawa Barat. Lokasi penelitian kedua adalah SDN Girigondo, Kaligintung, Kecamatan Temon, Kabupaten Kulon Progo, Daerah Istimewa Yogyakarta. Lokasi penelitian ketiga adalah SDN 1 Sangkawana yang berlokasi di Pagutan, Batukliang, Kabupaten Lombok Tengah, Nusa Tenggara Barat. Penerapan Sekolah Ramah Anak (SRA) di tiga sekolah tersebut, akan dievaluasi/dilihat dengan merujuk pada 6 komponen penting antara lain komitmen tertulis/kebijakan SRA, pelaksanaan proses pembelajaran yang ramah anak, pendidik dan tenaga kependidikan terlatih hak-hak anak dan SRA, sarana dan prasarana SRA, partisipasi anak, partisipasi warga diluar sekolah (orang tua, lembaga masyarakat, dunia usaha, pemangku kepentingan, dan alumni).

\section{METODE}

Penelitian ini menggunakan pendekatan kualitatif yang berlandaskan pada apa yang diungkapkan responden. Subyek dalam penelitian ini adalah kepala sekolah, guru, tenaga kependidikan, orang tua siswa, dan beberapa siswa kelas 6 . Saat mengambil data penelitian, peneliti dibantu oleh mitra yang merupakan alumni dari sekolah yang bersangkutan. Penelitian kualitatif sebagai penelitian yang bermaksud memahami fenomena dengan mendeskripsikan apa yang dialami subyek penelitian dalam bentuk deskriptif dalam konteks alami dan memanfaatkan berbagai metode ilmiah. Teknik pengumpulan data menggunakan observasi, wawancara, dokumentasi, dan tinjauan literature. Validitas data dilakukan dengan triangulasi sumber (Lian, Kristiawan, \& Fitriya, 2018). Menurut Sugiyono (2018), teknik analisis data untuk penelitian kualitatif terdiri dari reduksi data, tampilan data, dan verivikasi data.

\section{HASIL DAN PEMBAHASAN}

Analisis pertama dilakukan dengan melihat kondisi ruang kelas. Sebagian besar kegiatan belajar mengajar terjadi di ruang kelas, sehingga kondisi ruang kelas yang terawat membantu siswa lebih optimal dalam menuntut ilmu. Selain kebersihan yang terjaga, terawat juga diartikan kelas memiliki meja yang cukup untuk menampung semua siswa, memiliki ventilasi udara yang baik, dan penerangan yang cukup. Hasil penelitian di SDN 2 Hegarsari, SDN Kaligintung, dan SDN 1 Sangkawana menunjukkan kondisi ruang kelas di sekolah terawat dengan baik sehingga siswa merasa nyaman. 
Selain ruang kelas, guru harus menjadi role model untuk para siswa sebagai upaya menumbuhkan nilai-nilai karakter yang baik (Sutisna, Indraswati, \& Sobri, 2019). Berdasarkan hasil penelitian, ketiga sekolah sudah menerapkan budaya yang baik misalnya menyapa dan mengucapkan salam ketika bertemu guru. Harapannya, perilaku ini bisa dibawa siswa ketika bertemu dengan orang tua atau berperilaku di masyarakat. Guru di ketiga sekolah membimbing siswanya dalam hal menjaga kebersihan, dan mengajari mereka untuk senantiasa menggunakan bahasa yang sopan saat berkomunikasi. Setiap mengawali dan mengakhiri pelajaran guru membiasakan siswa berdoa bersama sesuai dengan keyakinannya. Berdoa bersama merupakan bagian dari penanaman moral dan nilai religius pada anak.

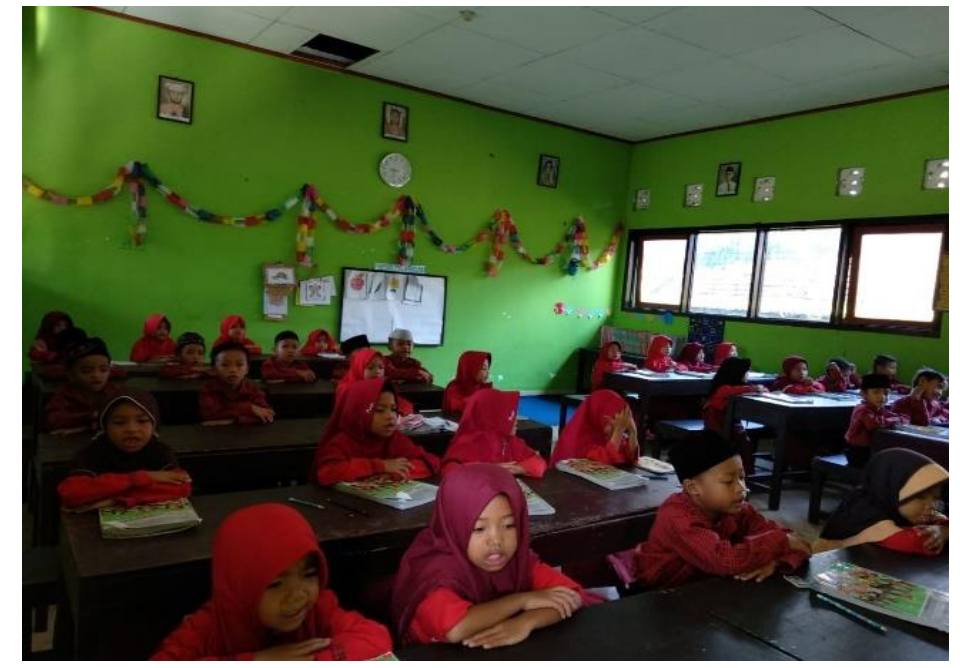

Gambar 1. Budaya doa bersama sebelum memulai pelajaran di SDN 1 Sangkawana

Di setiap kelas sudah terdapat tata tertib dan visi misi sekolah yang mudah dibaca oleh siswa. Tata tertib ini berfungsi untuk: (1) membudayakan hidup yang teratur dan terarah; (2) menumbuhkan rasa saling menjaga hak dan kewajiban; (3) mengajarkan perilaku disiplin dan rapi; (4) menumbuhkan persaingan yang sehat; dan (5) menjaga kebersamaan dan keharmonisan di lingkungan sekolah. Tata tertib membuat siswa semakin sadar dan terbiasa menaati peraturan dimulai dari lingkungan sekolah, sehingga nantinya mereka menjadi good citizen ketika sudah terjun di masyarakat.

Secara berkala, ada pertemuan yang melibatkan seluruh warga sekolah untuk membicarakan masalah yang terjadi dan solusinya, sehingga kondisi di lingkungan sekolah terkendali. SDN Kaligintung menjadwalkan pertemuan bersamaan dengan penerimaan hasil Penilaian Tengah Semester (PTS) dan Penilaian Akhir Semester (PAS). Sekolah harus memiliki program khusus untuk mempertemukan guru dan orang tua siswa. Fungsinya adalah untuk menghilangkan rasa curiga dan rasa sungkan, sehingga mereka dapat bekerja sama memberikan pendidikan yang baik bagi siswa. Kegiatan ini dilakukan untuk mengontrol kegiatan siswa. Orang tua menanyakan kondisi anaknya di sekolah, guru menanyakan kondisi siswanya di rumah. Jika anak tidak ada di sekolah maupun di rumah, maka semua pihak dapat bertindak. Kegiatan ini juga dapat berfungsi mengevaluasi kemajuan siswa. Jika siswa mendapat nilai yang kurang, guru dan orang tua dapat berkolaborasi mencari jalan penyelesaian untuk meningkatkan prestasi siswa. Komunikasi yang baik antara guru dan orang tua, membuat siswa memiliki dua pengayom yang dapat mencegahnya melakukan tindakan yang tidak etis.

Kelengkapan fasilitas yang dimiliki sekolah merupakan komponen penting yang menunjukkan bahwa sekolah menjamin kelancaran proses belajar siswa dengan menyediakan kebutuhan siswa. Terkait fasilitas, ketiga sekolah memiliki perpustakaan yang menunjang proses pembelajaran, sehingga kebutuhan siswa akan buku pelajaran terpenuhi. 
Ketersediaan perpustakaan sekolah juga menjadi sarana penting dalam menumbuhkan budaya membaca sejak dini. Ketiga sekolah juga memiliki kantin yang terjaga kualitas makanan dan minumannya (tidak membahayakan). Dengan begitu, orang tua siswa tidak perlu kawatir bila anaknya jajan di kantin sekolah. Sekolah juga memiliki unit kesehatan yang bekerja dengan baik dan layak sehingga anak yang sakit atau cidera di lingkungan sekolah bisa ditangani dengan baik. Untuk saat ini hanya SDN 2 Hegarsari yang memiliki koperasi yang menyediakan kebutuhan siswa sementara dua sekolah yang lain sedang mengusahakan dalam waktu dekat.

Anak memiliki kebutuhan bermain sebagai upaya mengembangkan kemampuan emosional, fisik, social, dan nalar mereka. Secara fisik bermain dapat mengembangkan kemampuan motoriknya. Secara social, anak belajar berinteraksi social, belajar berbagi, toleransi, dan bertanggung jawab. Ketersediaan tempat bermain di sekolah menjadikan anak bermain di tempat yang aman dan bisa dipantau. Hal ini juga memberikan ketenangan bagi orang tua siswa. Terkait komponen tempat bermain anak yang aman dan nyaman, di SDN 2 Hegarsari belum memiliki karena lahan terbatas tetapi siswa dapat bermain di lapangan serbaguna di dalam sekolah. Sementara di SDN Kaligintung dan SDN 1 Sangkawana sudah memiliki tempat bermain anak yang nyaman dan layak. Meskipun demikian, ketiga sekolah sudah menyediakan alat bermain anak yang layak sesuai kebutuhan siswa.

Kebersihan juga menjadi salah satu komponen penting untuk menjaga kesehatan lingkungan sekolah. Selain nyaman, lingkungan yang bersih juga dapat mencegah penyakit. SDN Kaligintung dan SDN 1 Sangkawana sudah menyediakan petugas kebersihan untuk menjaga kebersihan sekolah. SDN 2 Hegarsari melibatkan siswa dan guru piket dalam menjaga kebersihan sehingga siswa terbiasa disiplin menjaga kebersihan lingkungan sekolah.

Kehadiran guru bimbingan dan konseling (BK) di suatu sekolah juga penting karena setiap siswa memiliki pemikiran, sikap, kepribadian, dan perkembangan yang berbeda. Hanya SDN 2 Hegarsari yang memiliki guru BK untuk membantu siswa mengatasi persoalan baik dalam belajar maupun berperilaku dengan sesamanya. Guru BK memberikan pelayanan kepada siswa berupa (1) menemukan dan memahami pribadi siswa sehingga siswa mengetahui kelebihan dan kekurangannya; (2) memberikan bimbingan kepada siswa agar senantiasa belajar; dan (3) memberikan bimbingan kepada siswa untuk menempuh karier atau manata kehidupan. Kehadiran guru BK bukan hanya untuk siswa nakal atau bermasalah, tetapi membantu siswa menemukan dan memecahkan masalah yang ada dalam dirinya sekaligus memberikan motivasi untuk semangat mengejar cita-cita.

Maraknya kejahatan dari luar lingkungan sekolah seperti penculikan atau pencurian harus menjadi perhatian khusus bagi sekolah. Perlu bagi sekolah untuk memiliki petugas keamanan. Di SD N 1 Sangkawana sudah memiliki petugas keamanan yang melindungi siswa dari berbagai macam gangguan dan ancaman, sedangkan di SDN 2 Hegarsari dan SDN Kaligintung masih mempercayakan guru untuk menangani masalah keamanan di sekolah. Masyarakat yang bermukim di sekitar sekolah juga dapat berperan aktif menjaga keamanan sekolah dan mengawasi berbagai aksi tindak criminal di sekolah.

Terkait dengan kekerasan yang sering terjadi di lingkungan sekolah, ketiga sekolah memiliki aturan tertulis dengan sanksi yang tegas terhadap tindak kekerasan fisik maupun psikis yang dilakukan warganya termasuk menghina atau mengolok-olok karena fisik, mental atau kondisi social yang berbeda. Di SDN 2 Hegarsari dan SDN 1 Sangkawana sudah memiliki aturan yang melarang guru memberikan hukuman fisik dan ancaman pada siswa. Sedangkan di SDN Kaligintung belum memiliki aturan tersebut. Solusi atau penanggulangan tindak kekerasan yang terjadi terhadap anak mencakup: (1) Meningkatkan kesadaran siswa akan hak dan kewajiban di dalam hukum melalui latihan dan bimbingan secara berkesinambungan; (2) Meningkatkan kesadaran masyarakat betapa pentingnya usaha mengatasi terjadinya kekerasan terhadap anak di forum-forum pertemuan dengan wali siswa; (3) Meningkatkan kesadaran penegak hukum agar bertindak cepat dalam mengatasi kekerasan terhadap anak; 
(4) Bantuan konseling terhadap korban kekerasan terhadap anak; (5) Melakukan kampanye anti kekerasan terhadap anak; (6) Pembaharuan hukum terkhusus perlindungan korban tindak kekerasan yang dialami oleh anak serta kelompok yang rentang atas pelanggaran HAM; (7) Pembaharuan system pelayanan kesehatan yang kondusif guna menanggulangi kekerasan terhadap anak; (8) Membentuk lembaga penyantun korban kekerasan yang dapat diberikan secara cuma-cuma dalam bentuk konsultasi, perawatan medis, dan psikologis; dan (9) Meminta media massa memperhatikan masalah tindak kekerasan terhadap anak termasuk memberi pendidikan pada public tentang hak asasi anak (Pasalbessy, 2010).

Secara geografis, Indonesia terletak pada zona perbatasan tiga lempeng besar, hal ini menyebabkan frekuensi pergerakan lempeng sangat banyak. Pergerakan lempengan ini menjadi sumber munculnya gempa bumi tektonik (Suarmika \& Utama, 2017). Dari segi kegunungapian, Indonesia merupakan negara yang memiliki 127 gunung api aktif, dan 19 diantaranya ada di Pulau Jawa (Republika, 2019). Melihat potensi bencana yang terjadi, perlu adanya pendidikan mitigasi bencana di sekolah yang dapat membantu siswa memiliki pengetahuan, pemahaman, kesiapsiagaan, dan keterampilan dalam mengantisipasi bencana. Hal ini dapat mengurangi resiko kematian akibat bencana. Ketiga sekolah sudah menerapkan pendidikan mitigasi bencana, selain sosialisasi khusus juga ada penanaman pengetahuan yang disisipkan saat proses belajar mengajar berlangsung terkait upaya penyelamatkan diri apabila terjadi bencana baik gempa bumi, banjir, maupun kebakaran. Tetapi, ketiga sekolah belum menyediakan fasilitas pemadam kebakaran untuk mengantisipasi kebakaran karena belum ada kerjasama dengan dinas terkait.

Partisipasi siswa juga merupakan komponen penting SRA. Belajar akan optimal apabila siswa berpartisipasi aktif menyalurkan buah pikiran dan kreatifitasnya. Kesempatan akan partisipasi aktif siswa dapat mendorong pengembangan siswa dalam menerima respon dari luar, menanggapi permasalahan, dan menjawab permasalahan. Berdasarkan komponen partisipasi siswa, ketiga sekolah melibatkan siswa dalam penataan ruang kelas, tempat duduk, dan hiasan di kelas. Terdapat juga majalah dinding yang bisa dipergunakan siswa dalam menyalurkan kreatifitasnya. Di SDN 2 Hegarsari dan SDN 1 Sangkawana siswa memiliki jurnal harian dan sekolah mengikutsertakan siswa dalam pengambilan keputusan di sekolah, sedangkan di SDN Kaligintung tidak ada karena siswa sekolah dasar dirasa belum cukup umur untuk diikutsertakan dalam pengambilan kebijakan sekolah. Ketiga sekolah belum memiliki Organisasi Siswa Intra Sekolah (OSIS) sebagai wadah siswa dalam belajar organisasi karena dirasa mereka masih terlalu kecil, pembentukan organisasi dan ekstrakurikuler hanya sebatas yang dibutuhkan seperti pramuka, atletik, dan kesenian. Di SDN 2 Hegarsari dan SDN Kaligintung sekolah melibatkan siswa dalam penilaian kinerja guru sedangkan SDN 1 Sangkawana tidak.

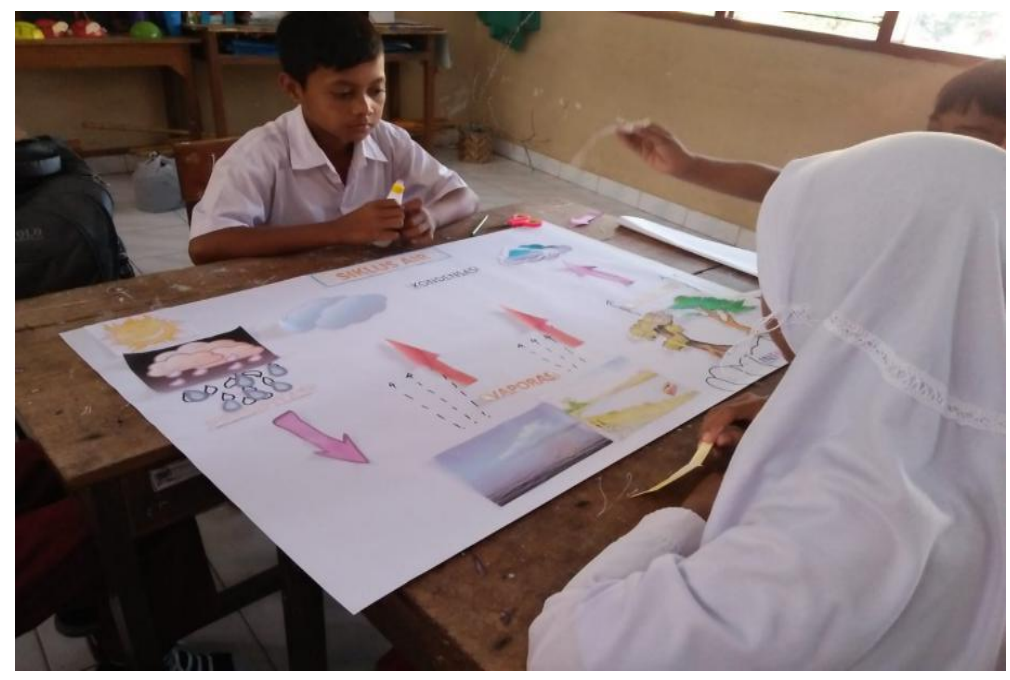

Gambar 2. Suasana KBM di SDN Kaligintung, Temon, Kulon Progo 
Ketiga sekolah juga secara berkala mengadakan lomba untuk meningkatkan potensi siswa misalnya dilaksanakan saat peringatan hari besar seperti Hari Pendidikan Nasional (Hardiknas) dan Hari Kartini. Ketiga sekolah juga memberikan apresiasi baik berupa piala atau hadiah atas prestasi siswa-siswanya. Ada tiga peranan penting dalam pemberian reward, antara lain: mempunyai nilai mendidik, memotivasi untuk mengulangi perilaku baik, dan memperkuat perilaku agar lebih optimal dan lebih baik lagi.

Saat memilih dan menentukan hukuman untuk mendisiplinkan siswa, ada beberapa hal yang perlu dipertimbangkan antara lain: (1) macam dan besar kecilnya pelanggaran; (2) melihat jenis kelamin, usia, halus dan kasarnya perangai; (3) akibat yang mungkin timbul dalam hukuman (jangan sampai menimbulkan akibat negative pada siswa); (4) memilih bentuk hukuman yang mendidik; (5) jangan memakai hukuman fisik. (Prima, 2016). Ketiga sekolah memperdulikan siswa yang tidak disiplin dengan pemberian sanksi yang mendidik disesuaikan dengan konteks ketidakdisiplinannya misalnya membuat puisi, atau menyanyi di hadapan teman-temannya.

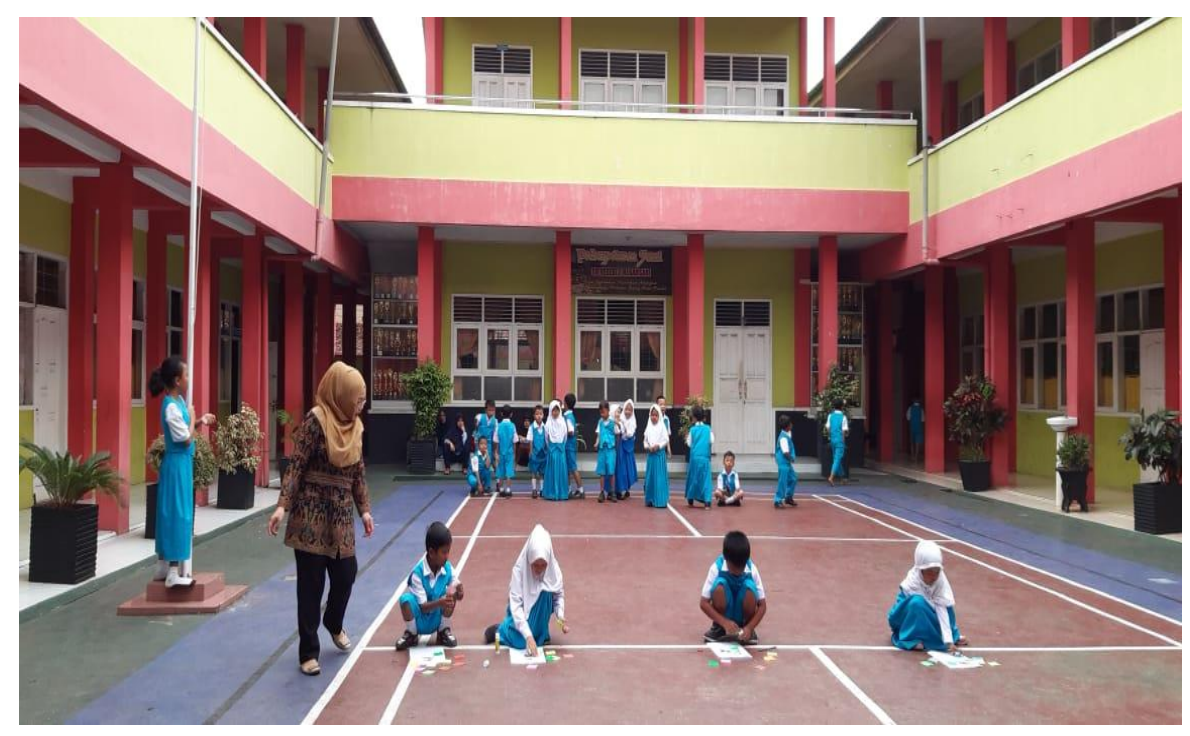

Gambar 3. Kegiatan games and learning di SD N 2 Hegarsari

Di SDN 2 Hegarsari dan SDN 1 Sangkawana, sekolah menyediakan masjid/mushola untuk melaksanakan kegiatan keagamaan, sedangkan di SDN Kaligintung siswa melakukan kegiatan keagamaan di Masjid yang terletak di depan sekolah. Di ketiga sekolah juga ada kebiasaan dari warga sekolah untuk menjenguk guru/siswa yang sakit atau mendapat musibah. Ada budaya menabung oleh siswa yang dikelola oleh guru kelas. Siswa juga dibiasakan untuk berinfak dan bersedekah di lingkungan sekolah. Kriteria kenaikan kelas juga tidak didominasi oleh aspek pengetahuan saja, tetapi ada juga aspek afektif dan psikomotorik sesuai kurikulum 2013. Guru juga menyajikan masalah konstektual sebagai contoh saat menjelaskan materi pelajaran.

Berdasarkan hasil wawancara dengan kepala sekolah di SDN 2 Hegarsari, sekolah ramah anak sangat perlu diterapkan di sekolah khususnya di sekolah dasar sebagai bentuk pemenuhan kebutuhan dan perlindungan anak dalam segala aspek. Diantaranya, spiritualitas (berkenaan dengan ketuhanan), intelegensi (berkaitan dengan berbagai kecerdasan), emosional (berkaitan dengan emosi fitrah manusia), sosial (berhubungan dengan manusia yang lain), dan estetika (berkenaan dengan hal-hal di dalam diri dan sudut pandang terhadap sesuatu). Dalam sekolah ramah anak ini perlu adanya pemenuhan nilai-nilai yang harus dikembangkan sebagai dampak pesatnya globalisasi. Orientasi dalam pemenuhan nilai-nilai tersebut adalah menghormati hak anak diantaranya kemandirian, kearifan lokal, pengembangan berpikir anak secara aktif, kreatif, inovatif, dan kritis. Sehingga tidak akan ada tembok penghalang bagi siswa dan guru untuk merealisasikan tujuan dalam pembelajaran. 
Senada dengan pendapat diatas, kepala sekolah di SDN 1 Sangkawana juga mengungkapkan di sekolah ramah anak, siswa bebas dalam mengeluarkan pendapat, tidak lagi dijadikan objek dan guru menjadi pihak yang paling benar. Guru harus bisa menjalin hubungan baik dengan anak-anak sehingga terjadi tujuan pendidikan yang "I am Ok You're OK" dan sesuai dengan Trilogi Ki Hajar Dewantara "Ing Ngarso Sung Tuladha, Ing Madya Mangun Karso, Tut Wuri Handayani”. Harapan kedepannya penerapan Sekolah Ramah Anak memiliki payung yang kuat dan berpedoman pada tujuan seperti apa, dan tidak lepas dari kearifan lokal tujuan pendidikan di Indonesia. Sehingga, tercipta pendidikan tidak hanya dalam pengembangan diri sebagai seseorang yang bisa berguna namun kebermaknaannya untuk mencapai manusia yang berpedoman pada ideologi bangsa. Tantangan di era globalisasi ini adalah kurangnya kepekaan terhadap sesama karena adanya degradasi moral yang tidak sesuai dengan kepribadian bangsa Indonesia berlandaskan Pancasila. Pengaruh paling besar adalah budaya luar. Anak-anak hanya mampu mengadopsi hal-hal yang tidak sesuai dengan agama maupun pancasila sehingga semakin terlihat dari penurunan kualitas dan semakin tidak terkendali. Hal tersebut dikarenakan modernisasi dan globalisasi sehingga mengakibatkan penyimpangan-penyimpangan sosial yang dilakukan anak-anak dikarenakan kurangnya pengawasan dari dalam maupun luar anak tersebut.

Sekolah Ramah Anak (SRA) merupakan sekolah yang memiliki kualitas proses belajar mengajar yang berpusat pada anak dan mencakup keterampilan hidup. Didukung oleh lingkungan belajar yang berkualitas dengan fasilitas, kebijakan, dan layanan yang memadai. SRA sangat memperhatikan kualitas pembelajaran, focus pembelajar, pengalaman dan kebutuhan, relevansi konten dan proses kurikulum, kualitas ruang kelas dan lingkungan sekolah yang luas, kesesuaian penilaian dengan berbagai aspek (melek huruf, berhitung, pengetahuan, sikap, kecakapan hidup), dan pencapaian hasil belajar (David, Bundy, \& Seung Lee, 2005). Sekolah tidak hanya berfungsi sebagai tempat menimba ilmu pengetahuan tetapi juga mengajarkan dan melatih siswa memiliki peranan social. Sekolah diharapkan dapat membentuk siswa menjadi manusia yang dapat bergaul dengan sesame meskipun memiliki perbedaan agama, suku bangsa, dan sebagainya. Siswa harus belajar menyesuaikan diri dalam situasi social yang berbeda (Utami, 2016).

Apabila dikaitkan dengan indicator pengembangan Sekolah Ramah Anak (SRA) menurut Peraturan Menteri Negara Pemberdayaan Perempuan dan Perlindungan Anak Republik Indonesia Nomor 8 Tahun 2014 Tentang Kebijakan Sekolah Ramah, terdapat 6 komponen penting, yaitu:

1. Kebijakan SRA. Ketiga sekolah memiliki Standar Pelayanan Minimal (SPM), adanya aturan tertulis dan kebijakan anti kekerasan, adanya penegakan disiplin yang mendidik dan tidak diskriminatif.

2. Pelaksanaan Kurikulum. Ketiga sekolah juga melakukan asesmen dan evaluasi terhadap pelaksanaan kurikulum. Misalnya, pengecekan terhadap RPP (tidak mengandung unsur kekerasan, pornografi, dan terorisme), pelaksanaan pembelajaran yang tidak diskriminasi terhadap siswa, penilaian yang obyektif terhadap komponen sikap, pengetahuan, dan keterampilan.

3. Pendidik dan Tenaga Kependidikan yang Terlatih Hak-Hak Anak. Sekolah memberikan kesempatan bagi guru untuk mengikuti workshop atau seminar yang muatannya mengarah pada bagaimana menjadi guru yang mampu menciptakan suasana yang ramah anak. Diharapkan dengan adanya pelatihan, guru semakin memahami hak-hak anak dan mampu berkontribusi membentuk lingkungan sekolah yang ramah anak.

4. Sarana-Prasarana Sekolah Ramah Anak (SRA). Ketiga sekolah sudah berupaya memberikan fasilitas yang ramah anak, seperti kantin, koperasi, mushola, tempat bermain, dan alat-alat permainan yang layak dan aman untuk digunakan. 
5. Partisipasi Anak. Ketiga sekolah memberikan ruang untuk partisipasi siswa, misalnya dalam penataan ruang kelas, majalah dinding, keikutsertaan dalam lomba, bahkan ada yang memasukkan penilaian siswa sebagai alat untuk evaluasi kinerja guru.

6. Partisipasi Orang Tua, Lembaga Kemasyarakatan, Dunia Usaha, dan Pemangku Kepentingan Lainnya dan Alumni. Di ketiga sekolah ada konsep sinergi antara sekolah dan orang tua siswa, hal ini agar didapatkan hubungan sinkronisasi antara kegiatan siswa di rumah dengan di sekolah. Misalnya dengan komunikasi efektif, orang tua bisa ikut memantau perkembangan anak di sekolah. Dengan masyarakat, sekolah bisa menjadi wadah untuk mendidik atau melatih siswa sesuai dengan kebutuhan masyarakat misalnya dalam kaitannya dengan muatan local

Sekolah perlu memiliki program bagi orang tua siswa, di dalam program tersebut ada berbagai kegiatan seperti sosialisasi program, sharing, dan masukan baik dari sekolah kepada orang tua siswa maupun sebaliknya. Dalam pelibatan orang tua, sekolah perlu menghimbau orang tua untuk ikut mengawasi kegiatan anak dirumah, seperti tontonan televisi, waktu bermain game, dan penggunaan internet. Orang tua juga perlu dihimbau untuk memberikan waktu khusus untuk mendengarkan permasalahan anak dan kejadian yang dialami di sekolah. Karakter anak dipengaruhi oleh pola asuh orang tua. Pola asuh orang tua yang salah menyebabkan anak memiliki perilaku yang salah baik di sekolah maupun di masyarakat. Pola asuh dibagi menjadi 3 yaitu otoriter, demokratis, dan permisif. Ciri pola asuh otoriter antara lain anak harus tunduk dan patuh pada kehendak orang tua, control terhadap tingkah laku anak sangat ketat bahkan tidak pernah memberi pujian, sering memberi hukuman fisik apabila anak tidak bisa memenuhi tuntutan orang tua. Pola asuh demokratis memiliki ciri orang tua memiliki aturan tetapi anak diberi kesempatan untuk mandiri dan mengembangkan control pribadi, anak dilibatkan dalam pengambilan keputusan. Pola asuh permisif memiliki ciri control orang tua kurang, bebas dan longggar, anak tidak dibimbing, tidak ada hukuman (Hanif, 2005).

Santrock (2007) mengemukakan para pelaku kriminal yang notabene masih remaja yang sedang dibina di Lembaga pemasyarakatan mengaku berasal dari keluarga broken home sering mengalami kekerasan fisik dan verbal tetapi ada juga sebagian dari mereka cenderung dibebaskan dan diabaikan oleh orang tuanya. Mereka beranggapan bahwa sekolah tidak memiliki manfaat, hanya sebatas pemberian pengetahuan secara terus-menerus. Dilihat dari sudut pandang dunia usaha, sekolah seharusnya memberikan keterampilan yang membuat siswa ketika lulus memiliki kompetensi yang dibutuhkan oleh dunia usaha. Sehingga semakin banyak lulusan bukan menjadi beban bagi negara. Perlu adanya sinkronisasi antara kebutuhan dunia usaha dengan apa yang diajarkan di sekolah. Hal ini tentunya harus menjadi evaluasi baik bagi orang tua, sekolah, dan pemangku kebijakan pendidikan.

\section{SIMPULAN DAN SARAN}

Hasil penelitian yang apabila dikaitkan dengan keenam indicator Sekolah Ramah Anak (SRA) menunjukkan bahwa Ketiga SD yang menjadi subyek penelitian (SDN 2 Hegarsari, SDN Kaligintung, SDN 1 Sangkawana) sudah menjadi sekolah ramah anak baik secara fisik maupun non fisik, meskipun ada beberapa sarana yang harus dilengkapi. Ketiga sekolah secara umum sudah menjadi tempat yang aman dan nyaman bagi siswa dalam melaksanakan proses belajar. Berdasarkan hasil penelitian terdapat beberapa saran antara lain: (1) Perlu adanya program mengenai upaya mewujudkan Sekolah Ramah Anak (SRA), sehingga evaluasinya mudah; (2) Adanya kerjasama dengan Dinas Pendidikan terkait dengan pengembangan Sekolah Ramah Anak (SRA); (3) Meningkatkan sarana dan prasarana sekolah terutama bagi siswa yang berkebutuhan khusus; (4) Sekolah perlu mengadakan pelatihan bagi guru terkait konsep Sekolah Ramah Anak (SRA) sebagai upaya pemenuhan hak-hak anak; dan (5) Mensinergikan semua pihak dalam upaya mewujudkan Sekolah Ramah Anak. 


\section{DAFTAR PUSTAKA}

David, C., Bundy, D., \& Seung Lee, E. (2005). Skills for health. Journal Nursing Management, 12(7), 39-39. https://doi.org/10.7748/nm.12.7.39.s23.

Hanif. (2005). Perbedaan tingkat agresivitas pada siswa SMU Muhammadiyah I Yogyakarta berdasar pola asuh dan jenis pekerjaan orangtua. Jurnal Penelitian Humaniora, 6(2), 144154.

Kumparan. (2019). KPAI: 153 Kekerasan Anak Terjadi di Sekolah, Pelakunya Mayoritas Guru. https://kumparan.com/kumparannews/kpai-153-kekerasan-anak-terjadi-di-sekolahpelakunya-mayoritas-guru-1sXmURDSLII. 2 Maret 2020 jam 10.16.

Lian, B., Kristiawan, M., \& Fitriya, R. (2018). Giving creativity room to students through the friendly school's program. International Journal of Scientific and Technology Research, $7(7), 1-7$.

Maslihah, S. (2006). Kekerasan Terhadap Anak: Model Transisional dan Dampak Jangka Panjang. Edukid: Jurnal Pendidikan Anak Usia Dini, 1(1), 25-33.

Patnani, M., Ekowarni, E., \& Etsem. (2002). Kekerasan Fisik terhadap Anak dan Strategi Coping yang Dikembangkan Anak. Indigenous, Jurnal IImiah Berkala Psikologi, 6(1), 4051.

Pasalbessy, J. D. (2010). Dampak tindak kekerasan terhadap perempuan dan anak serta solusinya. Jurnal Sasi, 16 (3), 8-13.

Poerwandari, E. K. (2008). Penguatan Psikologis untuk Menanggulangi Kekerasan dalam Rumah Tangga dan Kekerasan Seksual. Jakarta: Program Pascasarjana Universitas Indonesia

Prima, E. (2016). Metode reward dan punishment dalam mendisiplinkan siswa kelas IV di Sekolah Lentera Harapan Gunung Sitoli Nias. Jurnal Pendidikan Universitas Dhyana Pura, 1(2), 185-198. Retrieved from https://jurnal.undhirabali.ac.id/index.php/ Jepun/article/view/177

Putri, A., \& Santoso, A. (2012). Persepsi orang tua tentang kekerasan verbal pada anak. Diponegoro Journal of Nursing, 1(1), 22-29.

Qosim, M. N., Nugroho, I., Islam, P. A., Islam, F. A., \& Magelang, U. M. (2015). Implementasi sekolah ramah anak dalam membentuk budaya sekolah di SDN Geger Tegalrejo. Prosiding Konferensi Nasional ke- 7. Jakarta: Asosiasi Program Pascasarjana Perguruan Tinggi Muhammadiyah Aisyiyah (APPPTMA).

Santrock, J. W. (2007). Remaja (Benedictine Widyashinta, Penerjemah). Edisi ke-11. Jakarta: Erlangga

Soeli, Y. M., Djunaid, R., Rizky, A., \& Rahman, D. (2019). Analisis Faktor yang Berhubungan dengan Kejadian Perilaku Kekerasan pada Remaja. Jambura Nursing Journal, 1(2), 8595. https://doi.org/10.1017/CBO9781107415324.004.

Solihin, L. (2014) Tindakan Kekerasan pada Anak dalam Keluarga. Jurnal Pendidikan Penabur-No. 03/Th.II/Desember.

Suarmika, P. E., \& Utama, E. G. (2017). Pendidikan Mitigasi Bencana di Sekolah Dasar (Sebuah Kajian Analisis Etnopedagogi). JPDI (Jurnal Pendidikan Dasar Indonesia), 2(2), 18. https://doi.org/10.26737/jpdi.v2i2.327.

Sutisna, D., Indraswati, D., \& Sobri, M. (2019). Keteladanan Guru sebagai Sarana Penerapan Pendidikan Karakter Siswa. Jurnal Pendidikan Dasar Indonesia (JPDI), 4(2), 29-33. https://doi.org/http://dx.doi.org/10.26737/jpdi.v4i2.1236. 
Indraswati, et al., JKKP 7 (1) (2020) 51-62

Utami, W. S. (2016). Pengaruh Pola Asuh Orang Tua terhadap Agresivitas pada Persepsi Siswa Kelas IX. Indonesian Journal of Guidance and Counseling: Theory and Application, 5(1), 39-44. Retrieved from journal.unnes.ac.id/sju/index.php/jbk.

Widiastuti, D., \& Sekartini, R. (2005). Deteksi Dini, faktor risiko, dan dampak perlakuan salah pada anak. Jurnal Sari Pediatri, 7(2). 